\title{
Role of Co-curricular Activities (CCAs) in Academic Success and Increasing Graduate Employability
}

\author{
Khaled Karim, $\mathrm{PhD}$ \\ Department of Cognitive Sciences \\ United Arab Emirates University \\ P.O. Box 15551 \\ Al Ain, Abu Dhabi, UAE
}

Received: February 14, 2021 Accepted: March 1, 2021 Published: March 5, 2021

doi:10.5296/ijld.v11i1.18300 URL: https://doi.org/10.5296/ijld.v11i1.18300

\begin{abstract}
A significant body of research has investigated the impact of extra-curricular (ECAs) or co-curricular activities (CCAs) on academic performance. This review outlines the conceptual and theoretical value CCAs as they apply to students, faculty, staff, and employers of Higher Education Institutions (HEIs). The review also describes existing methods of integrating CCAs into post-secondary curriculum in order to increase graduate employability. Based on the findings from the existing literature, the review outlines some recommendations for HEIs to provide CCA opportunities to students to increase academic success and graduate employability.
\end{abstract}

Keywords: Co-curricular activities, extra-curricular activities, student success, higher education, employability, skills development, academic success

\section{Introduction}

While it is established that students' co-op positions, part-time work, internships and other forms of work-integrated learning provide students with valuable experience and competencies that can help as these students seek employment, there has been little recognition of the role that participation in extra-curricular or co-curricular activities might play in enhancing employability and in improving graduate outcomes (Stevenson, 2011). The aim of this literature review is to outline the conceptual and theoretical value of extra-curricular (ECAs) or co-curricular activities (CCAs) as they apply to students, faculty, staff, and employers of Higher Education Institutions (HEIs). The literature review will also describe existing methods of integrating CCAs into post-secondary curriculum in order to 
increase graduate employability.

This literature review is organized into the following sections:

1) Student involvement and the link to co-curricular activities

2) The impact/value of student involvement in CCAs

3) Summary of findings from the literature review

\section{Student Involvement and Co-Curricular Activities}

\subsection{Student Involvement Theory}

According to Astin's Involvement Theory (Astin, 1984), the effectiveness of any educational policy or practice is directly related to the capacity of that policy or practice to increase student involvement (Astin, 1984, p. 298). Leung, Raymong Ng and Chan (2011) added that, student involvement indicates the quantity and quality of physical and psychological energy that students invest in the post-secondary experience. Such involvement can take many forms, such as engaging in academic work, participating in extracurricular activities, and interacting with faculty and other staff members. Astin (1998), asserts that student learning and personal development are correlated with student's involvement, and the more students are involved in college activities, the greater their learning and personal development.

\subsection{Definition of CCAs}

The literature review did not uncover a precise definition of co-curricular activities (CCAs). In fact, the terms 'co-curricular' and 'extra-curricular' have been used interchangeably by some researchers to refer to out-of-class activities, e.g., volunteering, involvement in the community, and participation in club, sports and leadership activities. (The 1994 Group, 2009, p. 21). Other researchers have used either the ECA or CCA term, but not both.

Tan and Pope (2007) refer to co-curricular activities as extracurricular, extra-class, non-class, school-life, and student activities. Tchibozo (2007) considers extra-curricular as employment that sustains academic life, as well as leisure or social activities. Stuart et al. (2008) define extra-curricular activities (ECAs) as:

Part-time work, involvement in university students' union clubs and societies (and different types of clubs and societies, e.g., cultural, sporting and other), other university-related activities such as volunteering and class representation, involvement in other personal activities such as social networking sites, and other activities outside of university life, such as family commitments, religious involvement and community activities. In other words, activities outside of tutor-led learning time. (p. 6)

Referring to Stevens (1999), Leung, Raymond Ng and Chan (2011) assert that co-curricular activities are more student-centered than activities offered through regular classes. They add that in co-curricular activities, students assume responsible positions of leadership and the teacher-supervisor is often a mentor or guide rather than an instructor. 


\section{The Impact of Student Involvement in CCAs}

\subsection{The Correlation Between Students' Academic Learning and Personal Development Through CCAs}

Though conceptually sound empirical evidence of the relationship between co-curricular activities (CCA) and academic performance is rather inconclusive so far, research has found a positive correlation between co-curricular activities and other types of learning, and students' personal development (Cheng \& Zhao, 2006; Huang \& Chang, 2004).

In a survey-based study, Cheng and Zhao (2006) explored the relationship between students' participation in various organizations and activities and their self-perceived gains in multicultural competence. Questionnaires were distributed to 5,417 undergraduate students in a private residential college within a large American research university, and 2,921 responded. Statistical analysis of the data revealed a significantly positive effect of extracurricular activities on multicultural learning. Cheng and Zhao (2006) concluded that participating in college activities improved students' social and leadership skills, their multicultural competence and that, getting students involved in the activities was an essential step.

According to the 1994 Group's (2009) policy report, "studying for a degree helps students to enhance their intellectual confidence, logical thinking, communication and teamwork, and these skills are enhanced and broadened further by their engagement in activities such as volunteering, part-time work and involvement in their students' union” (p. 4). Huang and Chang (2004) investigated the relationship between different forms of involvement, and the optimal amounts and combinations of different forms of involvement for students' cognitive and affective growth. This included a survey of 627 third-year general education college students in Taiwan. The researchers found that students who had high levels of involvement in both academic and co-curricular activities reported the strongest gains in cognitive skills, communication skills, interpersonal skills, and self-confidence. To encourage co-curricular involvement, the researchers recommended that post-secondary institutions should use symbols and ceremonies to acknowledge and reward students' achievements in out-of-class involvement. They also advised student affairs practitioners to encourage CCA involvement by informing students and faculty of the positive learning outcomes.

\subsection{The Correlation between Participation in ECAs and Future Employment}

While exploring the ways in which extra-curricular activities (ECAs) benefit students, a number of researchers found that students' extra-curricular experiences have a significant impact on their future employment.

In a mixed method study (a survey of 631 second-year undergraduate students, followed by telephone interviews with 9 employers and 12 alumni) Stuart et al., (2011) investigated the effects of ECAs on students' experiences, outcomes and future job prospects in the UK. The study revealed that older and ethnic minority students spent more time with non-university ECAs, e.g., engaged in family, religious and solitary activities. Lower socio-economic status (SES) student spent more time working, and less time engaging in ECAs. The alumni reported that ECAs were key to developing self-identity, social networks and career prospects. 
According to employers, ECAs were valuable for 'distinguishing' job applicants, because they provided evidence of cultural fit, leadership, and commitment.

As also cited in Stuart et al. (2011) research paper, there were other studies (e.g., Blasko, 2002; Eide \& Ronan, 2001) that found positive correlations between students' ECA experiences and future employment. Eide and Ronan's (2001) study findings indicated that students' participation in competitive sports might have a positive effect on future earnings. Blasko's (2002) study revealed that younger students who participated in ECAs more than 10 hours per week were more likely to be successful in their subsequent employment. Rouline \& Banberter (2011) also referred to a few other studies (Cole et al. 2007; Chia, 2005; and Merino, 2007) that revealed such positive correlation between ECAs and future employment. Cole et al.'s (2007) study demonstrated that applicants whose résumé included more ECAs and leadership positions received better evaluations and more interview offers. According to Chia's (2005) study, students participating in ECAs received more job offers following their interviews. Furthermore, Merino's (2007) study revealed that university graduates who participated in ECAs found jobs corresponding to their qualifications more easily than graduates who didn't participate in such activities.

Based on a 2004 survey of 600 graduate students conducted in Canada, France and in the United Kingdom, Tchibozo (2005) explored how student life influenced students' entry into the job market. The data covered five types of social and leisure activities which the graduates carried on while studying: sports, student associations, activities in the social sector, citizenship activities and cultural activities. The findings revealed that students who participated in ECAs at a leadership level were more successful in finding work with larger firms, as well as finding positions with better job security and unemployment protection. On the other hand, students who participated in solitary activities were more likely to struggle to enter the job market and experienced higher rates of unemployment, less job security and lower occupational status overall.

In another study, Tchibozo (2007) investigated the effects of extra-curricular activity on 1119 UK graduates' transition from higher education to the labour market. It was found that ECAs had a significant influence on the transition process. For example, the graduates who engaged in ECAs at a leadership level had better access to managerial positions and the lowest risk of becoming unemployed before finding their first post-graduate position. Those who participated in citizenship activities or community work had immediate access to large employers during the transition period between school and work. Tchibozo (2007) concluded that extra-curricular experience gave students' access to higher occupational status, and also that the "results emphasize the strategic potential of extra-curricular activity for students and graduates wishing improved transition to the labour market" (p. 55). Tchibozo (2007) further suggests that graduates should highlight their "leadership" experience in their résumé, and that institutions should be encouraged to survey employers' extra-curricular preferences at the local level in order to assist graduates in building university-to-work transition strategies including effective extra-curricular participation.

Ramesh, Mann, and Parrot's (2014) study findings demonstrated that mathematics students 
could enhance employability skills by implementing relevant extracurricular activities throughout their degree programs. Ramesh et al. (2014) concluded that student feedback on the extracurricular activities was very positive and the implementation appeared to have played a role in enhancing their employability outcomes. In a more recent study, Milner, Cousins, and McGowan (2016) reported significant correlation between extracurricular activities and other employability related aspects of student experience, and students viewed it favorably in terms of CV building and enhancing employability. They also asked for the inclusion of students from less-privileged backgrounds.

\subsection{Need of CCAs to Enhance Future Employability}

Today's graduate employment market is extremely competitive. Students, therefore, need to equip themselves during their time at the college or university for a smooth and successful transition into the labour market. According to the 1994 Group's (2009) policy report, "employers (including businesses, charities, voluntary organizations and the public sector) greatly value the knowledge and skills that graduates develop whilst studying at university, along with the skills and experience they gain from undertaking activities beyond the curriculum" and that "the most employable graduates are those which not only possess such skills, but are able to reflect and articulate how they have developed their skills and why they are important" (p. 1).

Today's students recognize that having a degree will not guarantee a job and realize the need for acquiring additional credentials to differentiate themselves to employers. According to Rouline \& Banberter (2011). "Participation in extra-curricular activities (ECAs) is one such strategy, as it allows students to demonstrate competencies not otherwise visible in their résumés due to limited job experience" (p. 1). Rouline and Banberter further assert that the value of university degrees is decreasing in the labour market as it is hard for employers to differentiate between applicants who have the same academic credentials, but that ECAs can help solve this problem.

Tomlinson (2007) asserts that today's graduates believe that they need to add value and distinction to their credentials, as such distinction helps to place themselves at an advantageous position over their competitors. Rouline and Bangerter (2011) explored this in more detail by arguing that graduates are using ECAs to create distinct profiles as they apply for work positions. They surveyed 66 students from French-speaking Swiss universities to determine why these students were becoming involved in ECAs and how were these students using the ECAs as they entered the labour market. The researchers discovered that most students believed that their degree was not enough to ensure them a job after graduation and recognized the need to establish themselves as distinct from their fellow graduates. When options like completing internships and learning foreign languages were suggested, students indicated that participating in ECAs helped them build a distinctive profile as a potential employee, and helped them demonstrate how their education, experiences, accomplishments, interpersonal skills and character matched the job requirements.

Cole et al. (2009) support the idea that participation in ECAs can help an applicant express his or her personality. Hurtz and Donovan (2000) agree, and suggest that volunteering for 
community activities, for example, can be perceived as a signal of openness, and being member of a fraternity can be perceived as a signal of extraversion. Hurtz and Donovan suggest that employers particularly value these two personality traits because they are predictors of employee job or training performance. According to Rubin, Bommer, and Baldwin (2002), ECAs can be good indicators of individuals' competencies. For example, memberships in clubs or organizations and fraternities indicate peoples' interpersonal skills.

\subsection{Employer Perceptions of the Value of CCAs}

Several studies have investigated employers' perceptions of the value of extra-curricular or co-curricular experiences in graduate employability. Norwood and Henneberry (2006) measured the value that employers place on certain job qualifications for recent college graduates, with the goal to understand the important of qualitative attributes, such as students' perceived "character" and their passion towards career goals. A total of 339 employers and 534 undergraduate students from a college of agriculture in the US participated in the mail survey. The employers indicated that a candidate's character, passion, dedication toward career goals, and relevant work experience were very important. GPA and awards were the least important items in the attribute set. Students agreed with the employers' perceptions except for the value placed on a second language; students ranked this as the second most important attribute whereas employers ranked this as sixth.

Archer and Davison (2008) reported on a similar survey conducted by a group called International Employer Barometer (IEB). IEB surveyed 233 employers in the UK to determine which skills (including soft and hard skills) they valued most highly in university graduates. IEB's aim was also to find out which method of employment employers found the most useful and effective. The findings demonstrated that the top three most important skills and qualities that employers seek were communication skills, team-building skills and integrity. Both small and large companies indicated that work experience is important for the enhancement of graduates' employability skills. It was also revealed that $65 \%$ of employers with international partners or dealings indicated that professional work experience overseas makes applicants more desirable. Online recruitment was identified by the employers as the most effective method of graduate recruitment. Based on these findings, the researchers recommended that employer organizations should inform universities of their needs and try to work with universities to ensure that degree programs and student learning experience meets the needs of business.

The Gallup Organization's Eurobarometer survey (2010), conducted for the Directorate-General for Education and Culture (European Union), also provided insight into the perceptions and needs of graduate recruiters. While the main aim of the study was to identify the background of higher education graduates currently recruited in the surveyed countries, it also strove to determine the importance of various skills and abilities required by graduates; the factors that influence the level of graduate recruitment; and employer perspectives on how graduates could be made more employable. All 27 EU Member States, as well as Norway, Iceland, Croatia and Turkey were covered by the survey, and a total of 7,036 companies were interviewed using a fixed-line telephone methodology. The findings 
revealed that the ability to work in a team, decision-making skills, and computer literacy were considered to be important when recruiting higher education graduates. Also, $27 \%$ of the respondents strongly agreed with the statement that hired graduates had the skills required in their company, and $53 \%$ of the respondents expressed that work experience was a crucial asset for new recruits. While asked to identify the greatest challenges they faced in filling their vacancies, almost half (47\%) of graduate recruiters selected a shortage of applicants with the right skills and capabilities as the main reason.

\subsection{Faculty and Staff Perceptions on the Value of CCAs}

There is a lack of research literature on faculty and staff members' perceptions of the value of ECAs and CCAs in North America. Only one study on staff perceptions was found during the web search, which was conducted in the UK by Clegg, Stevenson, and Willott (2010). The researchers investigated staff conceptions of curricular and extracurricular activities in UK higher education. According to the researchers, "these understandings are crucial if learning from ECA is to be recognized, or at least accommodated, within the broader curriculum" ( $p$. 616). Interviews were held with 18 staff members selected from across the range of university courses, and to reflect different length of experience, seniority, gender and ethnic background. Six of the participants were at Principal Lecturer level. It was found that "there was considerable blurring of boundaries in conceptions of the curricular and extracurricular" and Clegg, Stevenson, and Willott (2010) argued that this was due to "the lack of any stable or explicit conception of the curriculum in UK higher education" (p. 615). Clegg, Stevenson, and Willott (2010) suggested that that co-curricular activities offered or organized by staff were outside the narrow lecture/teaching approaches outlined in the curriculum. According the researchers, there is a lack of debate about curricular matters and a "need for a clearer articulation of the qualities that might inhere in different sorts of activities and a recognition that the broad categories of work, volunteering, or caring for example can involve radically different experiences" (p. 623).

\section{Summary of Findings and Recommendations}

- Participation in extracurricular activities does not improve grades or educational expectations.

- ECAs have a positive effect on personal development. For example, ECAs help students achieve multicultural learning/competence, and also help them gain social and leadership skills. ECAs also contribute significantly toward gains in cognitive skills, communication skills, interpersonal skills, and self-confidence.

- ECAs significantly influence future employment. Certain types of ECAs have potential advantages in the job market. For example, ECAs undertaken at a leadership level can facilitate university graduates' access to large farms and managerial positions.

- ECA experience can be used by students to distinguish themselves in the highly competitive job market. 


\section{Macrothink Institute ${ }^{\text {TM }}$}

- Employers highly value ECA experience. Employers believe that ECAs are valuable for 'distinguishing' candidates, providing evidence of cultural fit, leadership, commitment, and 'selling' original activities. Employers also indicate that ECA experience can provide necessary employability skills to graduates. For example, communication skills, team-working skills, leadership skills, integrity are the skills employers value the most while hiring new graduates. Other qualitative attributes valued by employers are- high degree of personal character, passion and dedication to career goals.

- Staff members have misconceptions about the nature, value and learning outcomes of ECAs.

- There is a lack of research in on post-secondary student and staff perceptions of the value of CCR. Research is also lacking on the topic of CCR implementation and its operations at the post-secondary level.

\section{References}

1994 Group, The (2009). Beyond the Curriculum: Opportunities to enhance employability and future life choices. Retrieved January 20, 2020, from http://www.1994group.ac.uk/documents/public/091106_BeyondTheCurriculum.pdf

Archer, W., \& Davison, J. (2008). Graduate Employability: what do employers think and want? London, the Council for Industry and Higher Education (CIHE). Retrieved January 20, 2020, from http://aces.shu.ac.uk/employability/resources/0802Grademployability.pdf

Astin, A. (1984). Student involvement: A developmental theory for higher education. Journal of College Student Personnel, 25(4), 297-308.

Astin, A. W. (1998). The Changing American College Student: Thirty-Year Trends, 1966-1996. The Review of Higher Education, 21(2), 115-135.

Blasko, Z. (2002). Access to What? Analysis of Factors Determining Graduate Employability. Bristol: HEFCE.

Cole, M.S., Rubin, R. S., Feild, H.S., \& Giles. W. F. (2007). Recruiters' perceptions and use of applicant résumé information: Screening the recent graduate. Applied Psychology: An International Review, 56(2), 319-43. https://doi.org/10.1111/j.1464-0597.2007.00288.x

Cheng, D. X., \& Zhao, C. M. (2006). Cultivating multicultural competence through active participation: Extracurricular activities and multicultural learning. NASPA Journal, 43(4), 1338. https://doi.org/10.2202/0027-6014.1721

Chia, Y.M. (2005). Job offers of multi-national accounting firms: The effects of emotional intelligence, extra-curricular activities, and academic performance. Accounting Education, 14(1), 75-93. https://doi.org/10.1080/0693928042000229707

Clegg, S., Stevenson, J., \&Willott, J. (2010). Staff conceptions of curricular and extracurricular activities in higher education. High Educ, 59, 615-626. 
https://doi.org/10.1007/s10734-009-9269-y

Eide, E. R., \& Ronan, N. (2001). Is participation in high school athletics an investment or a consumption good? Economics of Education Review, 20(5), 431-42. https://doi.org/10.1016/S0272-7757(00)00033-9

Flash Eurobarometer No. 304. (2010). Employers' perception of graduate employability: Analytical report. Survey conducted by The Gallup Organization, Hungary upon the request of Directorate-General for Education and Culture, European Commission. Available on-line through Google: ec.europa.eu/public_opinion/flash/fl_202_sum_en.pdf Accessed: January 20, 2012.

Huang, Y., \& Chang, S (2004). Academic and Cocurricular Involvement: Their Relationship and the Best Combinations for Student Growth. Journal of College Student Development, 45(4), 391-406. https://doi.org/10.1353/csd.2004.0049

Hurtz, G.M., \& Donovan. J. J. (2000). Personality and job performance: The big five $\begin{array}{lllll}\text { revisited. Journal of Applied } & \text { Psychology, } & \text { 85(6), }\end{array}$ https://doi.org/10.1037/0021-9010.85.6.869

Leung, C., Raymond Ng, C., \& Chan, P. (2011). Can Co-curricular Activities Enhance the Learning Effectiveness of Students?: An Application to the Sub-degree Students in Hong Kong. International Journal of Teaching and Learning in Higher Education, 23(3), 329-341.

Merino, R. (2007). Pathways from school to work: Can the competences acquired in leisure activities improve the construction of pathways? Journal of Education and Work, 20(2), 139-59. https://doi.org/10.1080/13639080701314696

Milner, S., Cousins, W., \& McGowan, I. (2016). Does All Work and No Play Make a Dull Graduate? Perceptions of Extra-curricular Activities and Employability. Journal of Perspectives in Applied Academic Practice, 1(4), 13-18. https://doi.org/10.14297/jpaap.v4i1.183

Norwood, B., \& Henneberry, S. R. (2006). Show me the money! The value of college graduate attributes as expressed by employers and perceived by students. American Journal of Agricultural Economics, 88(2), 484-498. https://doi.org/10.1111/j.1467-8276.2006.00873.x

Ramesh, N., Mann, T., \& Parrott, K. (2014). Extracurricular activities to enhance the employment outcomes of Mathematics graduates. The Higher Education Academy. Department of Mathematical Sciences, University of Greenwich. Retrieved from http://gala.gre.ac.uk/14659/1/14659_RAMESH_Extracurricular_Activities_2014.pdf

Roulin, N., \& Bangerter, A. (2011). Students' use of extra-curricular activities for positional advantage in competitive job markets. Journal of Education and Work, I-first, 1-27.

Rubin, R.S., Bommer, W. H., \& Baldwin, T. T. (2002). Using extracurricular activities as an indicator of interpersonal skills: Prudent evaluation or recruiting malpractice? Human Resource Management, 41, 441-54. 


\section{Macrothink}

International Journal of Learning and Development

ISSN 2164-4063 2021, Vol. 11, No. 1

Stevens, C. W. (1999). Co-curricular activities: An element of solution-focused oriented interventions for middle school seriously emotionally disturbed students. Doctoral dissertation. Oregon State University.

Stuart, M., Lido, C., Morgan, J., \& May, S. (2008). Student diversity, extra-curricular activities and perceptions of graduate outcomes, York: Higher Education Academy.

Tan, D., \& Pope, M. (2007). Participation in cocurricular activities: Nontraditional student perspectives. College \& University, 83(1), 2-9.

Tchibozo, G. (2005). Effects and Strategic Potential of Extracurricular Activity in Higher Education. Research Paper. Canberra: Australian Association for Research in Education (AARE). Retrieved on-line from Google Scholar, January 30, 2012.

Tchibozo, G. (2007). Extra-curricular activity and the transition from higher education to work: A survey of graduates in the United Kingdom. Higher Education Quarterly, 61(1), 37-56.

Tomlinson, M. (2007). Graduate employability and student attitudes and orientations to the labour market. Journal of Education and Work, 20(4), 285-304.

\section{Copyright Disclaimer}

Copyright for this article is retained by the author(s), with first publication rights granted to the journal.

This is an open-access article distributed under the terms and conditions of the Creative Commons Attribution license (http://creativecommons.org/licenses/by/4.0/). 